\title{
EARTHQUAKE NEAR WHITTIER, CALIFORNIA, JANUARY 29, 1941*
}

\author{
By C. F. RICHTER
}

Authougr it alarmed many persons in Pasadena, Whittier, and other neighboring towns, the shock at 5:34 P.M., P.S.T., on January 29, 1941, was only a minor seismic event. Amplitudes recorded on the seismograms give a magnitude of 4.0 on the scale in use at Pasadena. ${ }^{1}$ The intensity sporadically reached VI on the Modified Mercalli Scale of 1931, as indicated by scattered instances of displaced furniture, broken dishes, ete. The reports indicate irregular and

\section{TABLE 1}

SHOCK OF JANUARY $29,1941,17^{\text {h }} 34^{\mathrm{m}}$ P.S.T.

Assumed $33^{\circ} 58^{\prime} \mathrm{N}, 118^{\circ} 03^{\prime} \mathrm{W}, h=15 \mathrm{~km}$.

\begin{tabular}{|c|c|c|c|c|}
\hline Station & $\Delta(\mathrm{km})$. & Time of $P$ & $\mathrm{P}-\mathrm{O}$ (sec.) & 0 \\
\hline Pasadena.. & 23.0 & $17: 34: 51.9$ & 4.9 & $17: 34: 47.0$ \\
\hline Mount Wilson. & 28.7 & 52.7 & 6.0 & 46.7 \\
\hline Riverside..... & 62.4 & 58.6 & 11.7 & 46.9 \\
\hline Palomar.... & 129.9 & $17: 35: 08.8$ & 22.2 & 46.6 \\
\hline Santa Barbara. . & 162.2 & 12.9 & 26.2 & 46.7 \\
\hline Haiwee......... & 240.8 & 22.8 & 36.1 & 46.7 \\
\hline Tinemaha........ & 347.6 & 36.3 & 49.6 & 46.7 \\
\hline
\end{tabular}

spotty distribution of intensity, probably associated with unusually short duration of shaking.

The shock was felt by most persons in the eastern and central part of the Los Angeles metropolitan area, and by a few as far as Santa Monica, Redondo Beach, and Long Beach. It was generally noticed in the eastern part of the San Fernando Valley, but not in San Fernando. Eastward, perceptibility extended to Claremont, but apparently not to Santa Ana. Outlying reports that the shock was felt by a few persons came from Riverside and from the Veterans' Hospital north of San Fernando.

The instrumental epicenter is exceptionally accurate, very closely $33^{\circ} 58^{\prime} \mathrm{N}$, $118^{\circ} 03^{\prime} \mathrm{W}$. Table 1 shows distances calculated from this epicenter, time of arrival of the first motion ( $\overline{\mathrm{P}}$ at the three nearest stations, $\mathrm{P}_{\mathrm{n}}$ at the others), and travel times and origin times on these data.

* Manuscript received for publication June 16, 1941.

1 C. F. Richter, "An Instrumental Earthquake Magnitude Scale," Bull. Seism. Soc. $A m ., 25: 1-32(1935)$. 
Calculations are based on the findings of Gutenberg:"

$$
\begin{gathered}
P-O=\frac{\sqrt{\Delta^{2}+h^{2}}}{5.55} \\
P_{\mathrm{n}}-O=5.8+\frac{\Delta}{7.94}
\end{gathered}
$$

where $h$, the depth of focus, is taken as $15 \mathrm{~km}$.; except that the elevation of Mount Wilson $(1.7 \mathrm{~km}$.) is allowed for by taking $h=16.7 \mathrm{~km}$.

The origin time was first approximated by using the apparent $\overline{\mathrm{S}}-\overline{\mathrm{P}}$ intervals at Pasadena, Mount Wilson, and Riverside, which were 2.9, 4.0, and 8.0 seconds, respectively, giving origin times at $47.8,47.1$, and 47.3 seconds after $17^{\mathrm{h}} 34^{\mathrm{m}}$. The epicenter given in table 1 was reached by trial and error. With the assumed velocities, epicenter and depth can only be altered by a kilometer or two within the limits of error of the data. The close accuracy with which it is possible to fit the assumed travel-time equations for $\overline{\mathrm{P}}$ and $\mathrm{P}_{\mathrm{n}}$ is thus an independent verification of these equations.

At Pasadena there is evidence of a remarkable one-sided displacement or fling, which commences with the arrival of the first transverse waves, increases to a maximum in about half a minute, and then returns toward zero in the next half minute. This effect is largest on the Benioff instruments with galvanometer periods of 100 seconds; but it is very clearly recorded on a torsion seismometer with period of 6 seconds. This instrument shows a permanent displacement of its zero, which is also shown by the torsion instrument with pendulum period of 0.8 second in the same $(\mathrm{E}-\mathrm{W})$ component. The effect corresponds to fling of the pendulums $\mathrm{N}, \mathrm{W}$, and $\mathrm{U}$. Impulsive earth motion causing this deflection would be in the opposite sense; but it appears that this must be a tilt, and therefore in the same direction as the pendulum motion. Similar permanent offsets of the zero for torsion seismometers have been observed at other stations (particularly at Riverside and Santa Barbara) in shocks originating close by. Such sudden shifts may account for the high accelerations occasionally deduced from the records of strong-motion instruments on the assumption that they are responding normally as inertial masses.

The epicenter is of geological and economic importance. The point is about one mile southwest of the center of the city of Whittier. The Whittier fault, passing through the hills to the north, is a thrust fault dipping north ward, not likely to be related to this shock. The Norwalk fault, on the other hand, passes a mile or two south of the epicenter; there is geophysical evidence ${ }^{3}$ that it rep-

${ }^{2}$ B. Gutenberg, "Travel-Time Curves at Small Distances, and Wave Velocities in Southern California," Gerlands Beiträge z. Geophysik, 35:6-45 (1932).

${ }^{3}$ B. Gutenberg and J. P. Buwalda, "Seismic Refiection Profile across Los Angeles Basin," (Abstract) Proc. Geol. Soc. Am. 1935, 327-328. 
resents an important active fault zone, bearing about the same relation ot the north boundary of the Los Angeles Basin that the Inglewood fault zone does to the south boundary. The location of the Norwalk fault south of Whittier is not known with precision; a northward dip would be reasonable.

Previous shocks in the same district are: (1) the damaging Whittier earthquake of July 8, 1929, to which Wood and Richter ${ }^{4}$ assigned an epicenter at

TABLE 2

Shocks near Norwalk and Whittier

\begin{tabular}{l|r|r|r|r|r}
\hline \hline \multirow{2}{*}{ Station } & \multicolumn{4}{|c}{ Date } \\
\cline { 2 - 6 } & July 8,1929 & Oct. 24, 1933. & Jan. 22, 1935 & Nov. 4, 1940 & Jan. 29, 1941 \\
\hline Time at Pasadena... & $08: 46: 11.7$ & $23: 00: 49.5$ & $01: 28: 54.3$ & $22: 04: 39.9$ & $17: 34: 51.9$ \\
Time at Mount Wilson & 12.6 & 51.3 & - & 41.7 & 52.7 \\
Time at Riverside... & 17.7 & - & $29: 02.8$ & 48.0 & 58.6 \\
Time at Palomar.... & - & - & - & 58.0 & $35: 08.8$ \\
Time at La Jolla..... & - & $01: 08.8$ & 12.4 & - & - \\
Epicenter, N lat..... & $33^{\circ} 54 ! 8$ & $33^{\circ} 57^{\prime}$ & $33^{\circ} 53^{\prime}$ & $33^{\circ} 57^{\prime}$ & $33^{\circ} 58^{\prime}$ \\
Epicenter, W long.... & $118^{\circ} 02^{\prime} .4$ & $118^{\circ} 08^{\prime}$ & $118^{\circ} 09^{\prime}$ & $118^{\circ} 08^{\prime}$ & $118^{\circ} 03^{\prime}$ \\
Magnitude.......... & 4.5 & 4.5 & 3.5 & 3.5 & 4.0 \\
\hline
\end{tabular}

$33^{\circ} 54.8 \mathrm{~N}, 118^{\circ} 02.4 \mathrm{~W}$, with some foreshocks and many small aftershocks; (2) a shock on October 24,1933 , located at $33^{\circ} 57^{\prime} \mathrm{N}, 118^{\circ} 08^{\prime} \mathrm{W}$; (3) a small shock on January 22, 1935, and (4) a small shock on November 4, 1940, assigned to the same epicenter as (2).

For comparison the times of first motion at the nearest stations in the five principal shocks are given in table 2.

${ }^{4}$ Harry O. Wood and Charles F. Richter, "Recent Earthquakes near Whittier, California," Bull. Seism. Soc. Am., 21:183-203 (1931).

[Balch Graduate School of the Geological Sciences,

California Institute of Technology, Pasadena, California,

Contribution No. 326] 